\title{
EL TEMA DE LA VIRGEN DE GUADALUPE EN JUAN CORREA
}

\section{Por Santiago Sebastián}

Poco sabemos de la vida de este pintor de la Nueva España; trabajó de 1675 a 1739. Su obra necesita un estudio crítico, y material no falta, es grande el número de lienzos catalogados por Toussaint en su Pintura colonial en México, manuscrito que dejó inédito y fue publicado en 1965 con acopio de notas de Xavier Moyssén, miembro del Instituto de Investigaciones Estéticas.

Remito al lector interesado a la magna obra de Toussaint y me limito por ahora al tema guadalupano, que por cierto no pasa desapercibido en el mencionado libro según vemos en la nota 8 del capítulo xxII.

La presente nota la motiva la existencia de cuatro cuadritos con las famosas apariciones de la Virgen de Guadalupe en la Colección Carlos Aguilera, de Barcelona; una de ellas está firmada por Juan Correa. En su origen formaron parte de un típico cuadro de la Virgen de Guadalupe, estas escenas estuvieron en los ángulos. Fragmentado el cuadro, quedó por una parte la protagonista, la Virgen de Guadalupe, cuyo paradero ignoramos, y por otra estas cuatro escenas; afortunadamente nos ha llegado la firma en una de ellas. Pese al testimonio de la firma, nada nos dice que sea obra atribuible a Juan Correa, al menos por comparación con las obras ya conocidas del pintor. Fue este encargo una obra devocional, copia bastante fiel del modelo solicitado. En un encargo como éste, la originalidad no era factor a considerar, por tanto habia que sujetarse al modelo. En opinión de Orozco y Berra:

Hasta el tiempo de Juan Correa el Viejo, ningún pintor habia sabido copiar con exactitud y verdad a la Virgen de Guadalupe, cuyas efigies eran buscadas con empeño por el amor nacional; el tomó los trazos sobre papel aceitado con el mayor esmero, y desde entonces se reprodujeron las Guadalupanas, sin faltarles ni una estrella, ni uno solo de los rayos (Diccionario Universal de Historia y Geografia, t. II, p. 564. México, 1853).

Se dice que Correa, a fines del siglo xvir o principios del xvilr, restauró el original de la Virgen de Guadalupe, a causa de la confianza que el Cabildo de la Basílica depositó en él; tuvo, pues, oportunidad de llevar a cabo un calco o imitación. Se ha llegado a suponer que vivió en una 
de las casas próximas al santuario, así que los paisajes pintados en los cuadros guadalupanos responden a la realidad.

El cuadro de tema guadalupano más antiguo, firmado por Juan Correa, es una copia del modelo original, se encuentra en la capilla de San Onofre, de Sevilla. En la parte inferior nos ofrece un paisaje, que se considera como resumen de todos los pintados anteriormente en el siglo xvir; están en él los quince monumentos marianos, el arco triunfal, el santuario, las capillas y todas las edificaciones. Otra copia de la Virgen de Guadalupe, firmada por Correa, hay en la casa de Guillermo Rodríguez Izquierdo, de Sevilla. También firma otro con el tema de Juan Diego ante el obispo Zumárraga en la casa de Antonio Viudas, en Madrid.

Al siglo xvil pertenecen dos lienzos, ambos copia de la Virgen de Guadalupe, firmados por Correa. Uno es propiedad de Manuel Romero Gómez, en la villa de Aznalcollar, Sevilla, que está fechado en 1704. El otro data de 1712 y pertenece a las monjas jerónimas de Santa Paula, en Sevilla.

Unidos estos cuadros a los mencionados por Toussaint nos damos cuenta que éste fue uno de los temas más repetidos. He añadido estos ejemplos gracias al libro de Joaquín González Moreno: Iconografia Guadalupana, México, 1959, que pasó desapercibido a Toussaint y colaboradores. Aún se encontrarán más ejemplares firmados, como éste que ha aparecido en la mencionada colección de Barcelona, y que procede de México a través de Andalucía. Parece que el lienzo fue fragmentado con fines comerciales, tal vez porque no se consideró interesante la figura central.

Agradezco al coleccionista Carlos Aguilera las facilidades concedidas, así como a mi amigo Salvador Moreno, que tanto se interesa por las huellas mexicanas en España, y que arregló la entrevista con el dueño de los cuadros.

Que esta breve nota sobre la Virgen de Guadalupe sirva para ese catálogo iconográfico que los investigadores mexicanos deben emprender lo antes posible. 
DOI: http://dx.doi.org/10.22201/iie.18703062e.1976.46.1059

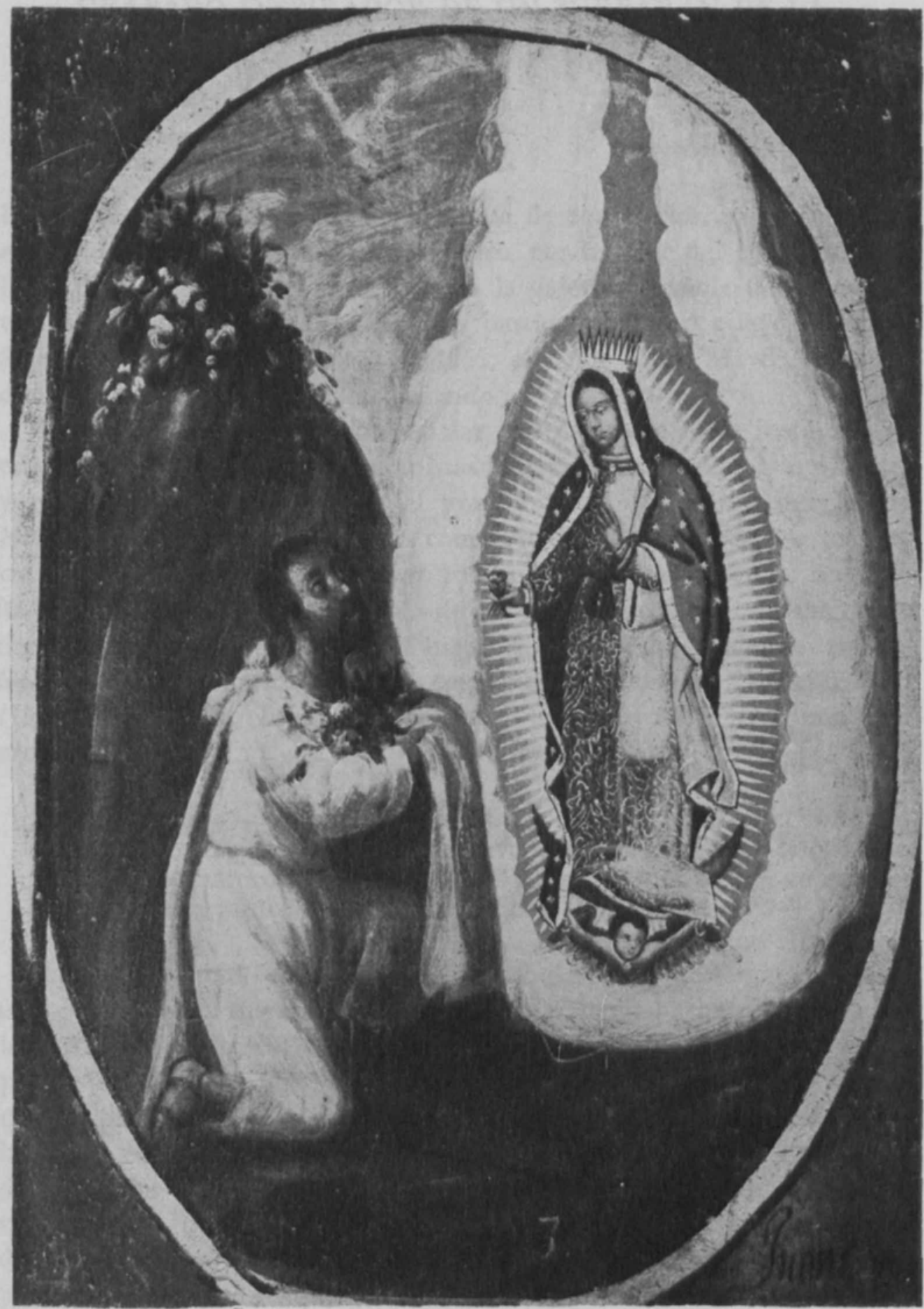

Figura 1. Juan Correa. La Virgen de Guadalupe. Colección Carlos Aguilera. Barcelona, España. 